\title{
Investigation and Analysis of Practice Teaching Base of Professional Postgraduate Student of Architecture and Civil Engineering
}

\author{
Cheng CHEN \\ College of Civil Engineering and Mechanics \\ Xiangtan University \\ Xiangtan, China
}

\author{
Wang LIU \\ College of Civil Engineering and Mechanics \\ Xiangtan University \\ Xiangtan, China
}

\author{
Zhong LIU \\ College of Civil Engineering and Mechanics \\ Xiangtan University \\ Xiangtan, China
}

\begin{abstract}
We investigated the construction status quo of offcampus practice teaching base of postgraduate student of architecture and civil engineering, and analyzed the existing problems of base construction from five aspects as the problems like unenthusiastic participation of cooperative enterprises, insufficient investment; incomplete base training conditions, imperfect management system, irresponsible off-campus tutor, and students expectations which cannot be satisfied. Therefore, we put forward reform proposals from multiple aspects like strengthening "double tutor" team construction, more investment for base construction, strengthening monitoring and evaluation, and supporting of laws and regulations to awaken postgraduate student education of professional degree and promote the improving of the education quality.
\end{abstract}

Keywords—professional degree; postgraduate student; teaching practice base; double tutor

\section{INTRODUCTION}

Teaching practice base is an important platform for integrating resources and training practice ability, innovation ability, and ability of analyzing and solving problems of fulltime professional postgraduate student. It's also a foundation for implementing practice teaching and an essential part in the process of professional postgraduate student training [1]. Practice proves that teaching practice base provides a great practical development environment for professional postgraduate student, and makes up the shortage of practical education training pattern of professional postgraduate student. This is beneficial for promoting the development of professional postgraduate student education [2]. After years of development, there are still considerable problems in the construction of teaching practice base. Therefore, the investigation of off-campus teaching practice base and carefully thinking of its problems are very important issues for optimizing the training pattern of full-time professional postgraduate student and improving the education quality. It also has very important practical significance for healthy development of full-time professional postgraduate student [3].

\section{INVESTIGATION OBJECTIVE, RESPONDENTS, AND INVESTIGATION CONTENT}

For investigating the status quo of teaching practice base construction and finding out existing problems, the study is carried out by ways of questionnaire and interviewing as taking the example of training pattern of professional postgraduate student of architecture and civil engineering.

\section{A. Investigation Objective}

We carries out questionnaire for investigating the status quo of off-campus teaching practice base construction to have a deeper understanding and awareness about incomplete fulltime professional postgraduate student training pattern and find out the existing problems so as to further improve the training pattern of full-time professional postgraduate student [4].

\section{B. Respondents}

The questionnaire respondents are divided into two modules. One of them possesses the qualification to recruit professional postgraduates of "architecture and civil engineering", and the module includes Xiangtan University, Hunan University of Science and Technology, Central South University, Hunan University, Changsha University of Science and Technology; the other one is enterprises and public institutions in school-enterprise cooperation for construction of teaching practice base, and they respectively are Hunan No.6 Engineering Co. LTD, Hunan No.3 Engineering Co. LTD, and Xiangtan Architectural Design Institute.

Foundation item: Key funded project of education science planning issues of Hunan Province (No. XJK015AGD010, XJK014AGD016) 


\section{Investigation content}

1) Satisfaction degree of postgraduate for the status quo of off-campus practice teaching base construction which includes hardware facilities, training conditions, and management system of teaching practice base, and practice course arrangement [5].

2) Satisfaction degree of postgraduate for the improvement of training ability of practice teaching base which includes professional theoretical level, practical ability, computer application ability, technological innovative ability, and ability of solving the practical engineering problems [6].

3) Satisfaction degree of postgraduate for off-campus tutors which includes working responsibility, practical teaching ability, and professionalism of off-campus tutors.

4) Supporting degree of school-enterprise cooperation units for teaching practice base which includes equipment fund investment, and improvement of economic benefits of enterprise, social benefits, technological innovative ability, and recognition of professional degree quality.

\section{Investigation Methods}

Questionnaire and interviewing are adopted. With combination of key funded project of education science "The Twelfth Five-Year Plan” issues of Hunan Province, from May to June in 2015, research group investigated 5 universities, 3 enterprises and public institutions, and gave out 200 questionnaires. Therein, Xiangtan University: 40; Hunan University of Science and Technology: 40; Central South University: 20; Hunan University: 20; Changsha University of Science and Technology: 20; Hunan No.6 Engineering Co. LTD: 20; Hunan No.3 Engineering Co. LTD: 20; Xiangtan Architectural Design Institute: 20. 196 questionnaires are collected, and take the proportion of $98 \%$.

\section{STATISTICAL ANALYSIS ON INVESTIGATION RESULTS}

A. Satisfaction Degree of Professional Postgraduate Student for the Status Quo of Teaching Base

TABLE I. SATISFACTION INVESTIGATION OF POSTGRADUATE FOR STATUS QUO OF TEACHING PRACTICE BASE CONSTRUCTION

\begin{tabular}{|c|c|c|c|c|}
\hline \multirow{2}{*}{ Investigation items } & \multicolumn{4}{|c|}{ Satisfaction degree (\%) } \\
\hline & Very satisfied & Satisfied & General & Not satisfied \\
\hline $\begin{array}{c}\text { Teaching practice base } \\
\text { hardware facilities }\end{array}$ & 35.4 & 32.7 & 27.2 & 4.7 \\
\hline $\begin{array}{l}\text { Teaching practice base } \\
\text { training conditions }\end{array}$ & 22.4 & 46.9 & 23.1 & 7.6 \\
\hline $\begin{array}{l}\text { Practice course } \\
\text { arrangement }\end{array}$ & 22.4 & 42.9 & 26.5 & 8.2 \\
\hline $\begin{array}{l}\text { Teaching practice base } \\
\text { management system }\end{array}$ & 21.8 & 46.3 & 25.2 & 6.7 \\
\hline
\end{tabular}

Statistical result of Table I shows, as adding up the percentage of Very satisfied and Satisfied, satisfaction degree of total Very satisfied and Satisfied of students for teaching practice base hardware facilities, teaching practice base training conditions, practice course arrangement, and teaching practice base management system respectively are $68.1 \%$, $69.3 \%, 65.3 \%, 68.1 \%$. On the whole, satisfaction degree of students for status quo of teaching practice base construction is under $70 \%$, and it's not good. Satisfaction degree of General is between $23.1 \%$ and $27.2 \%$, and of Not satisfied is between $4.7 \%$ and $8.2 \%$. The data shows that the conditions of practice base cannot satisfy the need of practical skills learning of students. Therefore, the construction of teaching practice base still has a lot of work to do. It seems that there is large potential power inside the base.
B. Investigation for Satisfaction Degree of Professional Postgraduate Student for Improvement of Training Ability of Practice Teaching Base

Statistical result of Table II shows, as adding up the percentage of Very satisfied and Satisfied, students who think teaching practice base can improve their practical ability cover the proportion of $72.1 \%$; students who think teaching practice base can improve ability of solving the practical engineering problems cover the proportion of $68 \%$; students who think teaching practice base can improve computer application ability cover the proportion of $66.6 \%$; students who think teaching practice base can improve technological innovative ability cover the proportion of $64.6 \%$; students who think teaching practice base can improve professional theoretical level cover the proportion of $56.7 \%$. The data proves that students improve their practical ability, ability of solving the 
practical engineering problems, computer application ability, technological innovative ability, and professional theoretical level in different degrees after the training of teaching practice base. Therein, the recognition of students for improving practical ability is the highest which the satisfaction degree of Very satisfied and Satisfied covers the proportion of $72.1 \%$. The recognition of the other four doesn't reach the proportion of $70 \%$. Satisfaction of General is between $20.4 \%$ and $25.9 \%$, and satisfaction of Not satisfied is between $7.4 \%$ and $12.3 \%$. There is a certain difference between investment and management of universities for teaching practice base construction. Students' expectations for improving practical ability through practice base are relatively higher as the situation of insufficient investment for practice base construction. Therefore, the investigation data for students' satisfaction degree can be foreseen.

TABLE II. SATISFACTION INVESTIGATION OF TEACHING PRACTICE BASE FOR POSTGRADUATE ABILITY IMPROVEMENT

\begin{tabular}{|c|c|c|c|c|}
\hline \multirow{2}{*}{ Investigation items } & \multicolumn{3}{|c|}{ Satisfaction degree \% } \\
\cline { 2 - 5 } & Very satisfied & Satisfied & General & Not satisfied \\
\hline $\begin{array}{c}\text { Improving professional } \\
\text { theoretical level }\end{array}$ & 30.6 & 36.1 & 25.9 & 7.4 \\
\hline Improving practical ability & 25.2 & 46.9 & 20.4 & 7.5 \\
\hline $\begin{array}{c}\text { Improving computer } \\
\text { application ability }\end{array}$ & 29.9 & 36.7 & 25.9 & 7.5 \\
\hline $\begin{array}{c}\text { Improving technological } \\
\text { innovative ability }\end{array}$ & 23.8 & 40.8 & 23.1 & 12.3 \\
\hline $\begin{array}{c}\text { Improving ability of } \\
\text { solving the practical } \\
\text { engineering problems }\end{array}$ & 31.3 & 36.7 & 20.4 & 11.6 \\
\hline
\end{tabular}

\section{Satisfaction Investigation of Postgraduate for Off-campus Tutors}

Statistical result of Table III shows, the satisfaction degree of postgraduate for the total of Very satisfied and Satisfied of off-campus tutors' professionalism, practical teaching ability respectively cover the proportion of $77 \%, 76.4 \%$; the satisfaction degree of postgraduate for the total of Very satisfied and Satisfied of off-campus tutors' working responsibility in practical teaching is $63.9 \%$ which decreased $12 \%$ to $13 \%$ in comparison with the first two. Compare with on-campus tutors, off-campus tutors should take the practical teaching as part of their job instead of extra work as students' wishes. They should also strengthen their working responsibility and fulfill the work responsibility carefully.

TABLE III. SATISFACTION INVESTIGATION OF POSTGRADUATE FOR OFF-CAMPUS TUTORS

\begin{tabular}{|c|c|c|c|c|}
\hline \multirow{2}{*}{ Investigation items } & \multicolumn{3}{|c|}{ Satisfaction degree \% } \\
\cline { 2 - 5 } & Very satisfied & Satisfied & General & Not satisfied \\
\hline $\begin{array}{c}\text { Tutors' working } \\
\text { responsibility of practical } \\
\text { teaching }\end{array}$ & 33.1 & 30.8 & 22.9 & 13.2 \\
\hline $\begin{array}{c}\text { Tutors' practical teaching } \\
\text { ability }\end{array}$ & 37.5 & 38.9 & 15.0 & 8.6 \\
\hline Tutors' professionalism & 40.1 & 36.9 & 18.5 & 4.5 \\
\hline
\end{tabular}




\section{ANALYSIS ON MAIN PROBLEMS AND ITS CAUSE OF TEACHING PRACTICE BASE}

Teaching practice base is an important platform for training practice ability, innovation ability, and ability of analyzing and solving problems. It's also a foundation for implementing practice teaching and an essential part in the process of professional postgraduate student training. Over the years, teaching practice base construction is lagging and the related subject officers do nothing for it. The hardware facilities and software facilities cannot meet the requirements of practical teaching. There are many problems of teaching practice base construction to be solved.

\section{A. Insufficient Cooperative Motivation for Teaching Practice Base Construction and Unenthusiastic Participation of Enterprises}

1) Focusing on the production and pursuing economic benefits are the eternal theme of enterprises. Economic benefits are the most fundamental driving force of schoolenterprise cooperation. Some of enterprises think the project of teaching practice base cannot bring much economic benefits for them, or even think practice base construction as extra work. Therefore, enterprises have unenthusiastic participations on the project.

2) Some of enterprises think the theoretical and practical knowledge which learned by professional postgraduate student in the enterprises may don't correspond with the need of actual work. Even, regular production of enterprises may be influenced sometimes. Enterprises not only have to assign the full-time staff to the guidance work, but also have to be responsible for the reception, production safety of students. That's not a good deal in their opinions.

\section{B. Unclear Boundaries of Responsibilities, Rights, and \\ Benefits between Universities and Enterprises}

In the process of teaching practice base construction, there are problems of unclear boundary of responsibilities, rights, and benefits between universities and enterprises. There is no clear responsibilities division between two sides in the aspects of teaching content, internship arrangement, and prevention of student accident. In the stage of practical training, there is no answer for the questions which like who has the priority to evaluate the academic performance, or how to reach a consensus between two sides.

\section{Lack of Actual Integration and Positive Interaction in the Cooperation of Teaching Practice Base Construction}

There is little positive interaction between universities and cooperative enterprises. Most projects of teaching practice base construction of school-enterprise cooperation are stay in a stage of nominal cooperative which only exists for the need of projects of student internship. Advantages of both sides cannot be developed and utilized fully as existing of following problems: lack of communication in the aspects of technology promotion, academic discussion, and scientific research between the two sides; lack of broad and deep of researches and discussions in the aspects of cooperative areas and development direction of teaching practice base; and lack of communication and interaction in the aspects of scientific achievements, technological resources, equipment resource and engineering practice experience.

\section{Lack of Operation Mechanism and Assessment Criteria}

Hanging the notice board of teaching practice base in the opening ceremony is just a nominal procedure. Lots of operation work is waiting to be done hereafter. There is a lack of serious discussion and systematic, scientific and standardized document requirements in the aspects of leading organ, working body, composition of staff from both universities and enterprises, funding, collaboratively providing, profit distribution, and incentive and restraint mechanism of teaching practice base. Besides, binding force of related agreement is limited, and there is also a lack of supervision and coordination of the third party.

\section{COUNTERMEASURES AND ADVICE}

We can see from the investigation above that training fulltime professional postgraduate student in the school-enterprise cooperation is facing some problems which are to be solved. Specific advice in the actual work as followings:

1) The knowledge of education for professional postgraduate student needs to be further improved. China needs high-end talents and high-quality labors instead of pseudo elite (people who only go after economic benefits) with the paper of high diploma. Universities have to treat the professional postgraduate student education and academic postgraduate student education alike. Policy support has to be given to professional postgraduate student education. To intensify structural adjustment of professional postgraduate student education is an essential process of implementation of strategic transformation of professional postgraduate student education.

2) Universities should be proactive to intensify schoolenterprise cooperation and to invite cooperative enterprises to participate the training process of professional postgraduate student. Educational reform has to be intensified, and training plan has to be made jointly. Thus, promoting effect of enterprises can be given play to professional postgraduate student education. In addition, universities should introduce advanced technology and scientific achievements to teaching practice bases to provide the training opportunities for enterprises employees. Then, win-win cooperation can be created.

3) "Double Tutors" team construction has to be strengthened and strict selection and appointment system for off-campus tutors has to be established. Off-campus tutors with political integrity and professional competence should be openly, fairly, and justly selected. On-campus tutors' team should also be enhanced by strict checking, reward and punishment system. Besides, management of on-campus tutors should be strengthened too. Thus, a superior tutor's team can be created to improve the education quality of professional postgraduate student. 
4) Teaching practice base construction should be intensified. More investment should be added. Operating conditions, standardizing system and scientific management should be improved to promote the base construction to a new stage.

\section{CONCLUSION}

After the questionnaires and interviewing, this paper concludes problems of off-campus teaching practice base construction of full-time professional postgraduate student like unenthusiastic participation of cooperative enterprises, insufficient investment; incomplete base training conditions, imperfect management system, irresponsible off-campus tutor, and students expectations which cannot be satisfied. This paper analyzes the cause of those problems from five aspects and puts forward reform proposals from multiple aspects like improving the social awareness, intensifying the schoolenterprise cooperation, strengthening “double tutor" team construction, more investment for base construction, strengthening monitoring and evaluation, and supporting of laws and regulations to awaken postgraduate student education of professional degree and promote the improving of the education quality.

\section{REFERENCES}

[1] ZHAO Lina, WANG Chuanyi. Educational quality assurance of fulltime professional postgraduate student of universities in China: responsibilities, experiences, problems, and countermeasures [J]. Academic Degrees \& Graduate Education, 2013 (2): 46-50. (In Chinese).

[2] LIU Chuntao, LIU Song. Literature review of training quality assurance system of professional postgraduate student [J]. Economic Research Guide, 2014 (16): 75-78. (In Chinese).

[3] LIU Jian, TONG Huawei, CUI Jie et al. Investigation and analysis of training status quo of professional postgraduate student [C]. Collection of the twelfth seminar of dean/department head of school/department of civil engineering of universities of China, Tongji University Press, 2014: 110-115. (In Chinese).

[4] CHEN Cheng, LIU Wang, LIU Zhong. Problems and countermeasures of full-time professional postgraduate student training of civil engineering [J]. Education and Teaching Forum, 2015 (30): 190-191. (In Chinese).

[5] WANG Jun, LIU Ruoyong. Investigation and analysis of teaching status quo of full-time professional postgraduate student --- taking seven 211 universities in Wuhan as examples [J]. Academic Degrees \& Graduate Education, 2012 (7): 18-22. (In Chinese).

[6] Xu Changqing. Evaluation report of education quality development of professional postgraduate student: taking research universities in southern China as examples [J]. Modern University Education, 2012 (3): 93-100. (In Chinese). 